\title{
EFFECT OF MOBILE BANKING ON FINANCIAL INCLUSION AMONG COMMERCIAL BANKS IN KENYA
}

\author{
Harwood Kajirwa Isabwa \\ Department of Economics, Accounts \& Finance \\ Jomo Kenyatta University of Science \& Agriculture, Nairobi, Kenya \\ isabwaharwood@mail.com, harwoodisabwa@yahoo.com
}

\begin{abstract}
Mobile banking is a precursor for the realization of financial inclusion among commercial banks in Kenya. The study's main objective was to determine the effect of mobile banking on financial inclusion among commercial banks in Kenya. The study adopted a positivism research philosophy. The study adopted an expo-facto research design because secondary data was the primary source data. The target population was 43 commercial banks in Kenya. The sample size was 39 commercial banks, but only ten commercial banks were selected because they had the best mobile banking apps. Inferential statistics adopted were; Pearson correlation and regression analysis. The study results revealed that mobile funds transfers significantly affect financial inclusion $(\beta=1.697, p=0.000)$. Cash withdrawals via mobile platforms significantly affect financial inclusion $(\beta=1.195, p=0.000)$. The study concluded that mobile banking has a significant effect on financial inclusion among commercial banks. In contrast, deposits via mobile platforms have a significant positive effect on financial inclusion $(\beta=.354, p=0.000)$. The study recommends that all financial institutions should adopt mobile banking as it helps to achieve financial inclusion. The banking sector should adopt the most appropriate mobile banking strategies to enhance financial inclusion.
\end{abstract}

Keywords: Mobile banking, financial inclusion, Commercial banks, Kenya

\section{How to Cite:}

Isabwa, H. K. (2021). Effect of mobile banking on financial inclusion among commercial banks in kenya. International Journal of Business, Management \& Econominc, 2(3). 184-197. DOI: https://doi.org/10.47747/ijbme.v2i3.315

\section{Introduction}

Financial inclusion plays a significant role in realizing an all-inclusive social, political and economic development in any country. Sharma, Khan and Thoudam (2019) opine that most poor people in underdeveloped and developing countries are unable to access financial services that will help them meet all their financial needs. The banking sector has a great responsibility to adopt the most appropriate strategies to enhance financial inclusion. This is because the 
strategies are meant to delineate all financial services to be delivered to a disadvantaged group of people at an affordable cost as per their needs and requirement. They are also meant to bring the unbanked and under-banked people into the financial system to provide them with the opportunity to access financial services to create economic growth and lead to empowerment opportunities (Lenka \& Barik, 2018).

Mobile banking strategies are advocated for as a determinant of the realization of financial inclusion. The strategies lead to expanding financial services to non-financial sectors and expanding essential services to individuals since nearly $50 \%$ of people in the developing world already own a mobile phone (World Bank, 2014). Currently, financial innovations exist via mobile phones and similar devices, launched in at least 80 countries (GSMA, 2014) to encourage millions of poor customers to use digital financial services rather than cash-based transactions exclusively. These financial innovation strategies help banks as suppliers or providers of financial services lower costs by reducing queuing lines in banking halls, reducing manual paperwork and documentation, and maintaining fewer bank branches (Manyika, Lund, Singer, White \& Berry, 2016). Besides these strategies, the latest World Bank estimates that around 2.5 billion people in the world do not have a bank account (World Bank, 2014). Global Findex data for 2012 reveal that only around 50\% of adults in the world have at least one bank account in the formal financial system.

However, this percentage of individuals with a bank account varies considerably between developed and developing countries. In developing countries, banking penetration rates are far below the average. In Africa, the percentage of adults with a bank account is $20 \%$, and in Latin America, 39\% (Bara \& Mudzigiri, 2016). The problem of involuntary financial exclusion requires intervention to address market failures such as asymmetric information, lack of competition in the markets or insufficient infrastructure. These failures make it difficult for specific population groups, low-income groups or those who have traditionally been more vulnerable, such as women, young people or people who live in rural areas, to use formal financial services (Yawe \& Prabhu, 2015).

Mobile banking refers to accessing banking services and facilities using electronic mobile devices such as mobile phones (Olweny \& Shipho, 2011). It involves using a mobile phone or another mobile device to undertake financial transactions linked to a client account (Kigen, 2010). The services include performing balance checks, account transactions, payments, credit applications and other banking transactions through a mobile phone. Mobile banking strategy is geared towards realizing inclusive access to financial services and or products offered by financial institutions. In Kenya, financial access is already very high, especially compared to other countries in Africa and Asia. In this setting, the momentum around expanding access has plateaued. However, a new narrative is taking hold around deepening engagement with financial services, more active use, and the use of a broader range of more advanced services.

The 2016 Financial Inclusion Insights (FII) data shows that financial engagement is becoming more meaningful for customers already included. In 2016, almost 7 in 10 Kenyan adults held a registered account with a formal financial institution. Mobile money continued to lead in terms of access and account registration. Approximately 97 per cent of those who had a financial 
account in 2016 had a mobile money account, sometimes in addition to a bank and microfinance account (Boro, 2017). While the number of registered users plateaued, advanced use of a registered account increased in 2016. Such advanced usage includes saving, borrowing, paying bills, and other activities beyond person-to-person transfers and cash deposits and withdrawals. Savings was the most common advanced use case for bank and mobile money accounts, followed by bill pay and receiving wages (Musango, 2014).

These findings show that mobile money services can fill a range of needs beyond personal payments. Kenya progresses towards improved financial inclusion, driven by mobile money and deepening engagement with advanced services. More must be done to ensure these advances are truly inclusive and result in meaningful outcomes for all Kenyans. Therefore, the current study sought to determine the effect of mobile banking on financial inclusion among commercial banks in Kenya. The remainder of this article paper is organized as follows. Section 2 covers a review of past studies, and it defines the research hypothesis, section 3 covers materials and methods, section 4 covers the results and discussion. In contrast, section 5 covers the conclusion and recommendations.

\section{Literature Review}

\subsection{Mobile Banking and Financial Inclusion}

Mustangs (2018) examined the role of Mobile banking services on financial inclusion among commercial banks in Nairobi city county, Kenya. The purpose of this study was to investigate the role of mobile transfer of funds, mobile payment for goods and services, bank account management over the mobile platform and mobile credit facilitation on financial inclusion in Kenya. The study was anchored on technology acceptance theory, diffusion of innovation theory and theory of financial intermediation. The study adopted a descriptive research design. The target population was the number of mobile money users across both banked and non-banked populations in Nairobi City County. The study relied on primary data collected by the use of structured questionnaires. The data was presented using both descriptive and inferential statistics. Findings of the study established that mobile transfer of funds, mobile payment for goods, mobile account management, and mobile credit facilitation significantly influenced financial inclusion in the economy.

Wakaba and Wepukhulu (2019) examined the effect of mobile money services on Kenya's financial inclusion. The main objective was to determine the effect of Key mobile money services on financial inclusion in Kenya. The study adopted a census research design. The target population was limited to the four firms (Safaricom, Airtel, Equity and Telkom) providing mobile money services in Kenya. The study relied on secondary data. The study review period was between 2013 and 2018. Descriptive statistical approaches, regression and correlation analysis was used to analyze secondary data. The study established that the Mobile money deposit services, Mobile money-saving services and Mobile bill payment services positively and significantly affected Kenya's financial inclusion. 
Ngugi (2015) examined the relationship between mobile banking and financial inclusion in Kenya. The study sought to determine the relationship between mobile banking and financial inclusion in Kenya. Mobile banking was operationalized using several mobile users with access to the mobile phone, the number of subscribers who have enrolled for the mobile money services and the number of mobile money agents who convert mobile money to real cash. The study used secondary data obtained from the Central Bank of Kenya and the communication authority of Kenya for the period 2006 to 2014. The study adopted a descriptive research design. Multiple regression analysis was used to obtain the relationship between financial inclusion and mobile banking services. The significance of the results obtained was determined using analysis of the variance. The study found that mobile money transfer services have a positive effect on financial inclusion in Kenya. The study further found that mobile banking services have contributed significantly to deepening financial markets, primarily from financial products related to mobile money developed. Mobile banking services were also found to have contributed significantly to financial access in Kenya.

Mtetwa (2018) examined the impact of mobile banking on financial inclusion. The study adopted quantitative data collection methods. The study adopted a survey to capture data of statistical nature on the impact of mobile banking services on financial inclusion. The sample size was 95 mobile banking customers. The study area was in Dzivarasekwa, Seke and Epworth low-income suburbs. The study results revealed that mobile banking services have a positive impact on financial inclusion. Boro (2017) researched the effect of mobile banking on financial inclusion in Kenya. The study adopted quarterly secondary data for the period 2006 to 2016. The data collected were analyzed using both descriptive and inferential statistics. Descriptive statistics comprised trend analysis for the years under consideration. Inferential statistics comprised of both correlation and regression analysis. The study results revealed that mobile banking has a significant positive effect on financial inclusion in Kenya.

Mutsune (2014) examined financial inclusion using mobile banking in Kenya. The study examined Kenya's extremely successful cash transfer model, MPESA, with the intent to assess the nature and part of financial inclusiveness in stimulating economic activity. The researchers' concentrated on assessing the structure that can approximate how Kenya's financial inclusion over banking using mobile phones has influenced economic dynamism. The research found out that there was a positive and significant correlation between mobile banking and financial inclusion.

Ishengoma (2011) studied banking via mobile phones system coverage for financial addition in Tanzania in the Coast Region at Kibaha district council. The target population comprised individuals registered who were subscribed to mobile services and the agents who offered mobile banking systems. Approximately 20.4 million Tanzanians had been registered with mobile service providers at that time. The study exhibited a positive association and statistically significant link between mobile banking and financial inclusion. In Zimbabwe, Mago and Chitokwindo (2014) investigated the influence of mobile banking on financial inclusion at Masvingo Province. The study sample size was 270 respondents, comprised of 50 from the formal sector, 50 from the informal sector, and 20 tertiary scholars. The districts of Chivi, Bikita, 
Gutu and Masvingo were chosen and constituted the sample size. The results revealed that the poor individuals were prepared to accept mobile banking, and they further revealed that mobile banking was readily available, convenient, cheap, user-friendly and safe. In a nutshell, the study exhibited a positive association and statistically significant link between mobile banking and financial inclusion.

Akter, Anwar, Mustafa and Ali (2021) conducted a study on revisiting the impact of mobile banking on financial inclusion among developing countries. The study aimed to explore mobile banking facilities' effect on financial inclusion in 17 developing countries. The study period was between 2011 and 2017, and this study took data from the three dimensions of financial inclusion called "penetration," "access," and "uses". Financial inclusion was measured using the Sarma model of the Index of Financial Inclusion (IFI). Their research article incorporated mobile money accounts as a "penetration" variable and mobile banking outlet as an "access" variable with existing model variables to quantify the effect of mobile banking. It was established that mobile banking positively impacts the selected countries, though the degree of the changes is not symmetric. African regional countries had improved their financial inclusion after introducing mobile banking much better compared to other regions.

Blaise and Kosgei (2021) researched the effect of mobile banking on financial inclusion in Burundi. The study's specific objectives revolved around establishing the effect of mobile money distribution, mobile money transactions and the value of mobile money transactions on financial inclusion in Burundi. The target population was 14 institutions that offer mobile banking services, and only three were sampled due to their data availability. The descriptive research design and data from secondary sources were also used from the year 2012 to 2019. The study results revealed that mobile money distribution was not statistically significant hence not an essential determinant of financial inclusion in Burundi. On the second specific objective, the significance value showed that mobile money transactions were statistically significant determinants of financial inclusion. On the last specific objective, the regression co-efficient value of mobile money transactions was not statistically significant; hence the variable was not a good determinant of financial inclusion in Burundi.

Wakaba and Wepukhulu (2019) studied the effect of mobile money services on Kenya's financial inclusion. The study aimed to determine the effect of Key mobile money services on financial inclusion in Kenya. The study adopted a census research design. The target population comprised four firms (Safaricom, Airtel, Equity and Telkom) that provided mobile money services in Kenya. The study adopted secondary data. The study review period was between 2013 and 2018. Descriptive statistical approaches, regression and correlation analysis was used to analyze secondary data. The study established that mobile money deposit services, mobile money-saving services, agency banking services and mobile bill payment services positively and significantly affected Kenya's financial inclusion.

Kabala, Mapoma, Nalutongwe, Muyani and Lungu (2021) studied an ethnological analysis of the influence of mobile money on financial inclusion in urban Zambia. The research article aimed to investigate the influence of mobile money on financial inclusion using urban Kitwe and Kalulushi as case studies. An ethnographic methodology was adopted to understand how mobile 
money has encouraged the unbanked population to access financial products and services. The findings revealed that mobile money has a positive influence on financial inclusion. It is easier to open accounts with mobile money kiosks than with traditional banks. Mobile money services are conveniently located where the unemployed, aged and other segments of the unbanked population are found. They use mobile money services to send and receive money, pay utility bills and purchase airtime.

Keli (2018) studied the effect of mobile technology on financial inclusion in Kitui County, Kenya. This study was guided by four objectives; examining the effects of access to mobile phones on financial inclusion in Kitui county, Kenya, determining the effect of financial products offered through mobile phone technology on financial inclusion in Kitui county, assessing the effect of quality mobile phone services on financial inclusion in Kitui county, Kenya and finally assessing the effect of freedom to choose mobile network operator on financial inclusion in Kitui county, Kenya. The study adopted a systematic research design. This study targeted a population of 7060 individual residents of significant towns of Kitui County. The target population included clients of MPESA agents, petrol stations, supermarkets and mobile banking agents. The study used a stratified sampling technique to select a sample of 351 . The research used a questionnaire to collect data. Data were analyzed using both descriptive and inferential statistics. The study revealed that there is a positive impact between financial inclusion and mobile phone technology used. The mobile operators reported generating high revenues from mobile money transfers, which was fueled by many consumers moving money in their bank account using their mobile phones. Further, the Ease of access to mobile services networks has been a critical contributor to enhancing smooth service delivery in financial inclusion.

Usavi (2014) studied the impact of mobile banking on financial inclusion in Buhera District in Zimbabwe. The study's objectives were to analyze coverage of M-Banking for financial inclusion, the usage behaviour of mobile subscribers to M-Banking services, identify drivers and inhibitors of mobile banking, and assess service effectiveness and service cost charges. The study adopted a survey research design. The population sample size to be considered was 64 . Both primary and secondary were adopted. Data was collected using questionnaires and interviews, administered to mobile subscribers and retail agents of the mobile banking systems. Secondary data was collected through an intensive review of the reports, journals, books, and magazine and internet materials. The results revealed that $78 \%$ of the population understudies were using the M-Banking system technology, of which almost $100 \%$ has helped in efficiently accessing financial services. It further shows that illiterate populations are facing difficulty in using technology compared to literate ones. Also, the service cost charges were still not apparent to the study.

Businge (2018) studied the usage of mobile banking services and the financial inclusion of rural populations in Rwanda. This study aimed at determining the impact of mobile banking on financial inclusion. Descriptive and analytical methods were adopted mixed with correlation on a sample size of 246 estimated using Slovin's formula from a target population of financial providers in Karongi District totalling 634. Questionnaires were adapted to collect data which 
was then analyzed using both descriptive and inferential statistics. It was established that mobile money, agent, ATM banking technologies were adopted, but the majority of the respondents adopted mobile banking. The study results also revealed sufficient evidence to conclude that mobile banking positively affects financial inclusion through the various technologies. The literature reviewed led to the following hypothesis statement: $H_{01}$ : Mobile banking has no significant effect on financial inclusion among commercial banks in Kenya.

\section{Research Method}

Positivism research philosophy was the ideal research philosophy. The study was guided by hypotheses, which all are attributes of a positivism research philosophy. An expo-facto research design was adopted because the study used secondary data that the researcher could not manipulate. The target population was 43 commercial banks in Kenya. The sample size was 39 banks determined using Slovins (2012) sample size determination formula:

$$
n=\frac{N}{1+N e^{2}}
$$

Where;

$\mathrm{n}=$ required responses

$\mathrm{N}=$ Population

$\mathrm{e}^{2}=$ error limit $(0.05)$

$$
\mathrm{n}=\frac{43}{1+43 * 0.05^{2}}=\frac{43}{1.1075}=38.8 \approx 39
$$

Purposive sampling was applied to the 39 banks to determine the banks offering mobile banking services. Out of the 39 banks, ten banks with the best mobile banking apps were considered in this study. The banks were Kenya commercial bank, Co-operative bank, Equity Bank, Barclays Bank, SBM Bank, Family Bank, NIC Bank Kenya, Eco Bank, National Bank, and CFC Stanbic Bank. Time series data for five years, i.e. between 2015 and 2019, was considered in this study. Secondary data was the primary source of data which was drawn from the central bank of Kenya. SPSS version 25.0 aided in data analysis. The study adopted descriptive statistics and inferential statistics such as mean, standard deviation, correlation and regression analysis, respectively, at a $5 \%$ significance level. The regression model adopted was as follows:

$$
\gamma=\beta_{0}+\beta_{1} X_{1}+\beta_{2} X_{2}+\beta_{3}+\varepsilon .
$$

Where;

$\gamma$ represents financial inclusion which is an amalgam of the value of the deposit as well as

the amount borrowed via mobile banking app

$X_{1}$ represents the value of mobile funds transfers

$\mathrm{X}_{2}$ represents the value of cash withdrawals 
$\mathrm{X}_{3}$ represents deposits via a mobile platform

$\beta_{0}$ represents the intercept

$\beta_{1}, \beta_{2} \& \beta_{3}=$ coefficient of $X_{1}, X_{2} \& X_{3}$ while "e" represents the error term

Assumptions of multiple linear regression were as follows; linearity of residuals, normality of residuals, multicollinearity, the autocorrelation of residuals and homoscedasticity. KolmogorovSmirnov and Shapiro-will tests were conducted. Linearity of residuals was tested using the value of significance for deviation from linearity based on the ANOVA output table. The interpretation is that if the value of significance of deviation from linearity is more significant than 0.05 , then the relationship between the independent variables and the dependent is linear and vice versa (Lind, Marchal \& Wathen, 2012). The normality of residuals was tested using the KolmogorovShapiro-Wilk test. Shapiro-Wilk test was adopted in the study. The assumption is upheld if the pvalue is greater than 0.05 .

Multicollinearity means that there is the absence of a perfect linear relationship between explanatory variables. Multicollinearity was tested using the variance inflation factor. If the variance inflation factor (VIF) is greater than 10, it implies serious multicollinearity problems (Williams, 2015). Auto-correlation of residuals was tested using the Durbin-Watson d test (Kothari, 2004). The "d"can assume values between 0 and 4 . The rule of thumb is that the values of $1.5<\mathrm{d}<2.5$ show no autocorrelation in the data. Homoscedasticity was tested using a scatter plot. The homoscedasticity assumption is met if the residuals do not fan out in a triangular fashion.

\section{Results and discussions}

\subsection{Correlation Analysis}

It was undertaken to assess the nature of the relationship between mobile banking strategy and financial inclusion. Mobile funds transfer had $\left(\mathrm{r}=.708^{*}, \mathrm{p}=0.000\right)$. Cash withdrawals $(\mathrm{r}$ $=.564 * *, p=0.000)$. Deposits via mobile platform $\left(\mathrm{r}=.916^{*}, \mathrm{p}=0.000\right)$. The results are shown in Table 1:

Table 1: Correlations Matrix

\begin{tabular}{|c|c|c|c|c|c|}
\hline & & $\begin{array}{l}\text { Financial } \\
\text { Inclusion }\end{array}$ & Transfers & Withdrawals & Deposits \\
\hline Financial & Pearson & 1 & & & \\
\hline inclusion & Correlation & & & & \\
\hline & $\begin{array}{l}\text { Sig. } \\
\text { tailed })\end{array}$ & & & & \\
\hline \multirow[t]{3}{*}{ Transfer } & Pearson & $.708^{*}$ & 1 & & \\
\hline & Correlation & & & & \\
\hline & $\begin{array}{l}\text { Sig. } \\
\text { tailed })\end{array}$ & .000 & & & \\
\hline Withdrawals & Pearson & $.564^{* *}$ & $1.000^{* *}$ & 1 & \\
\hline
\end{tabular}


Vol. 2, No. 3, August 2021

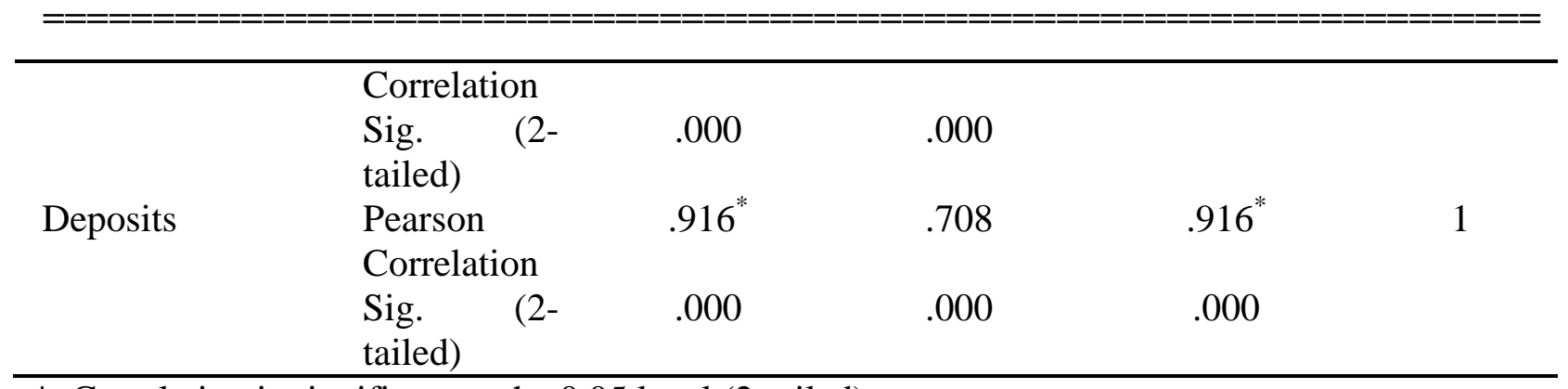

*. Correlation is significant at the 0.05 level (2-tailed).

**. Correlation is significant at the 0.01 level (2-tailed).

\subsection{Regression Analysis}

Multiple linear regression analysis was adopted to predict financial inclusion from mobile banking strategy. Linearity of residuals assumption was tested using a scatter plot, and it was upheld because the scatter plots did not follow a curvilinear pattern.

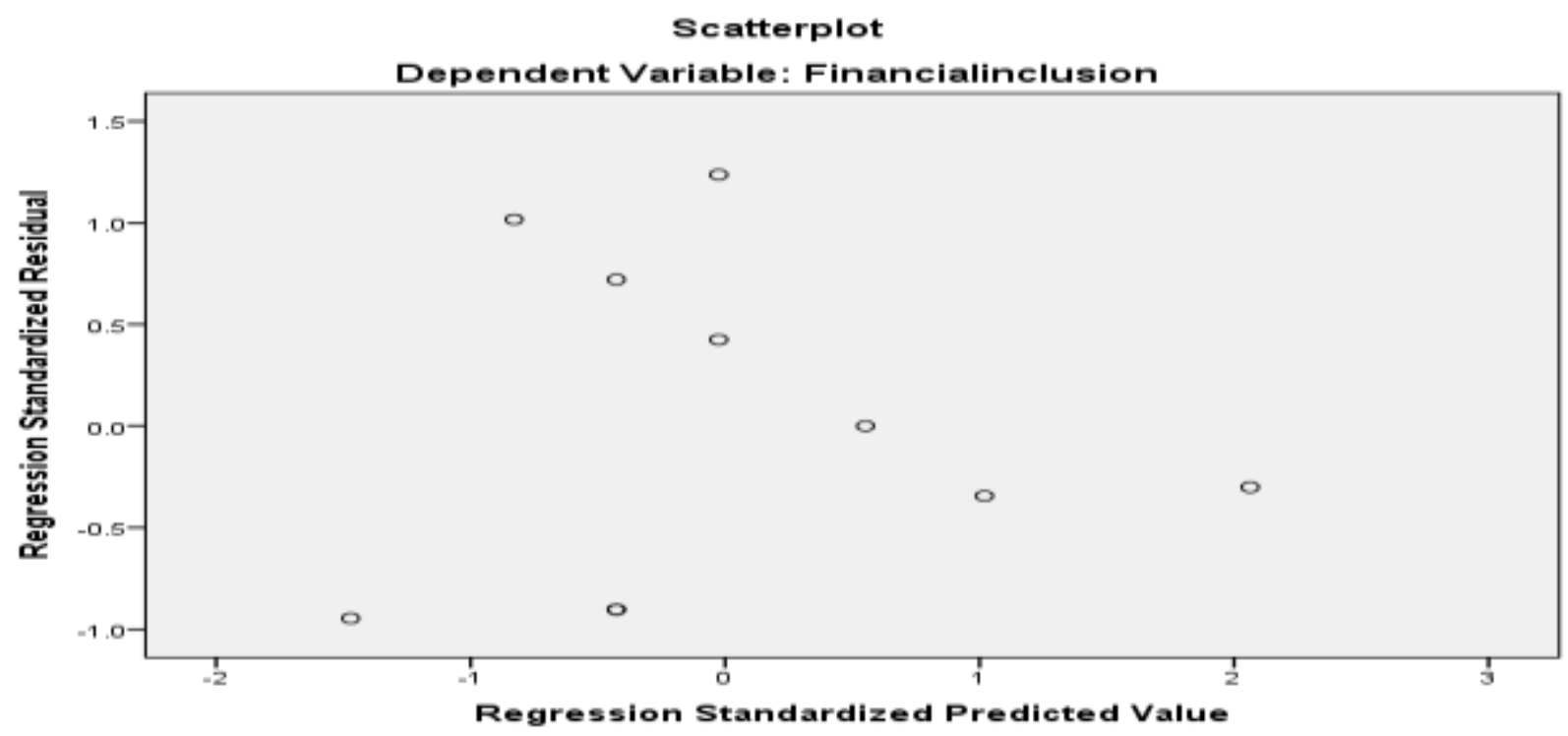

The normality of residuals was tested using Kolmogorov-Smirnov and Shapiro-will test. Shapiro- Wilk had a p-value of .338. The residuals were therefore normally distributed.

Table 2: Tests of Normality of Residuals

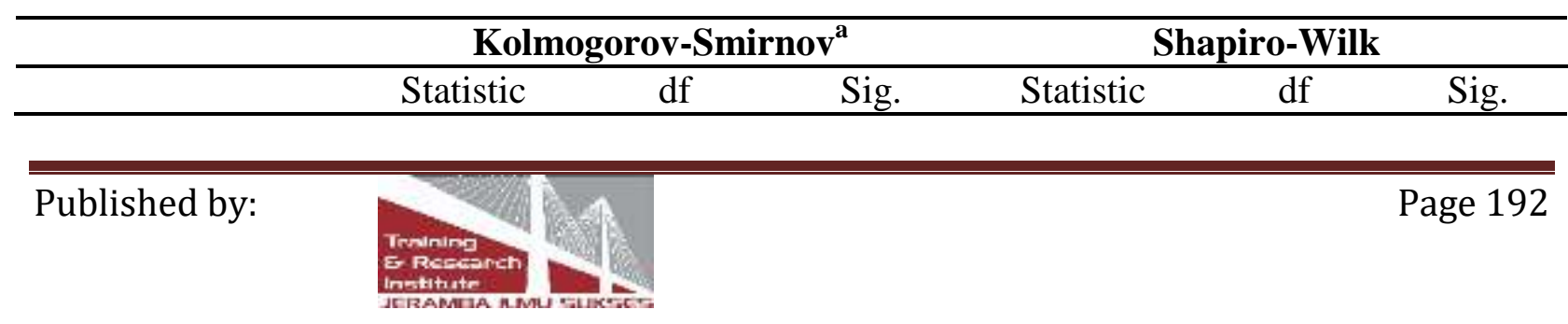


Vol. 2, No. 3, August 2021

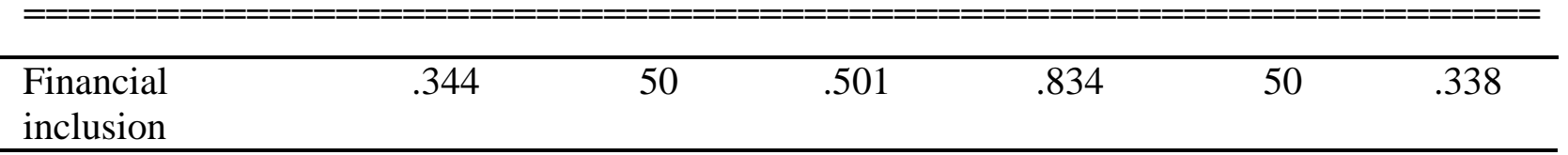

a. Lilliefors Significance Correction

Multicollinearity was tested using the variance inflation factor. The results were as shown in Table 3:

Table 3: Multicollinearity

\begin{tabular}{llccccccc}
\hline Model & & \multicolumn{2}{c}{$\begin{array}{c}\text { Unstandardized } \\
\text { Coefficients }\end{array}$} & $\begin{array}{c}\text { Standardized } \\
\text { Coefficients }\end{array}$ & t & Sig. & Tolerance & VIF \\
\hline \multirow{6}{*}{1} & & $\boldsymbol{\beta}$ & $\begin{array}{c}\text { Std. } \\
\text { Error }\end{array}$ & Beta & & & & \\
& & & & & & & & \\
& (Constant) & 49.927 & 2.888 & & 17.285 & .000 & & \\
& Transfers & 1.697 & .149 & 1.490 & 11.391 & .000 & .918 & 1.090 \\
& Withdrawals & 1.195 & .121 & 1.136 & 9.846 & .000 & .770 & 1.299 \\
& Deposits & .354 & .043 & .419 & 8.211 & .000 & .789 & 1.268 \\
\hline
\end{tabular}

a. Dependent Variable: inclusion

If the variance inflation factor (VIF) is greater than 10, it implies serious multicollinearity problems (Williams, 2015). In this study, there was no multicollinearity problem. There was no auto-correlation of residuals as the Durbin-Watson's d test was 2.290. It was within the expected range of $1.5<\mathrm{d}<2.5$ (Saunders et al., 2009).

Table 4: Auto-correlation of Residuals

\begin{tabular}{lccccc}
\hline Model & R & R Square & $\begin{array}{c}\text { Adjusted R } \\
\text { Square }\end{array}$ & $\begin{array}{c}\text { Std. Error } \\
\text { of the } \\
\text { Estimate }\end{array}$ & $\begin{array}{c}\text { Durbin- } \\
\text { Watson }\end{array}$ \\
\hline 1 & $.978^{\text {a }}$ & .956 & .953 & .45941 & 2.290 \\
\hline
\end{tabular}

a. Predictors: (Constant), transfers, withdrawals, deposits

b. Dependent Variable: Financial inclusion

Homoscedasticity of residuals assumption was tested using a scatter plot. The rationale is that if the residuals do not fan out in a triangular fashion, it means that the homoscedasticity assumption is met. The residuals do not fan out in a triangular fashion implying that the homoscedasticity assumption was upheld. 


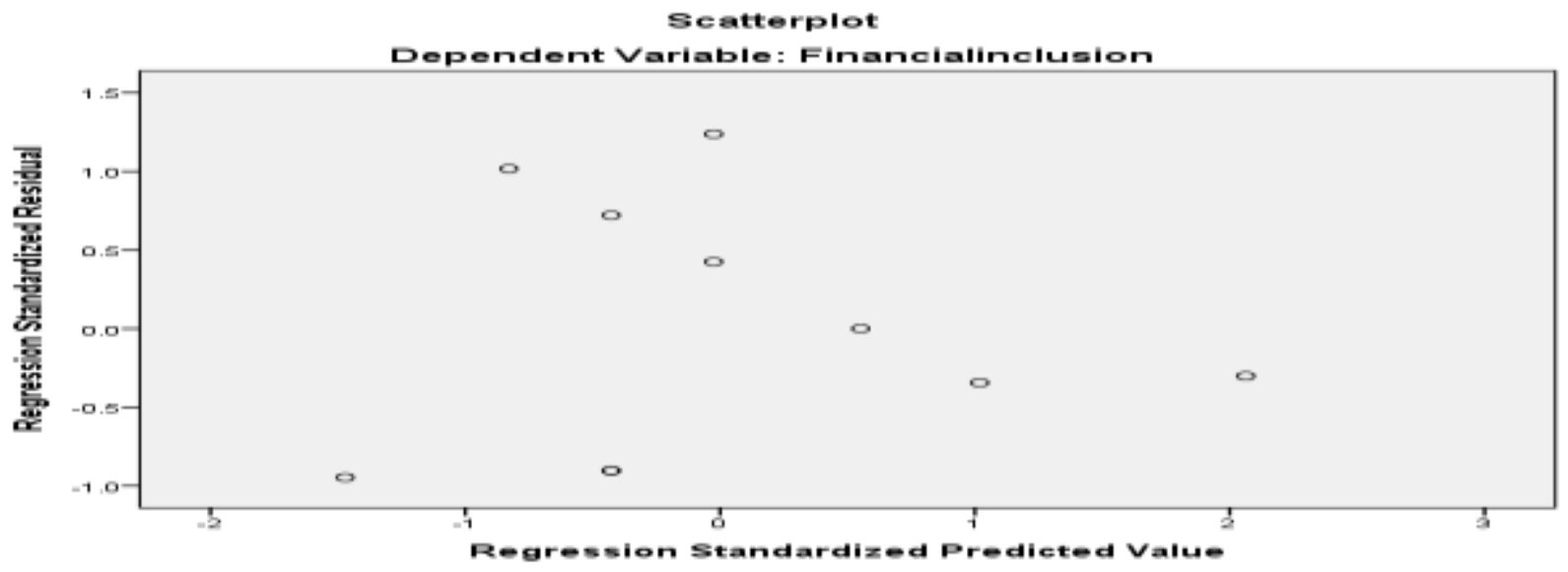

From the results in Table $5, \mathrm{R}=.978, \mathrm{R}$ square $=.956$, adjusted $\mathrm{R}$ Square $=.953$, and the standard estimate error $=.45941$. $\mathrm{R}$ coefficient relates to correlation. In contrast, $\mathrm{R}$ square is used to indicate the magnitude within which financial inclusion changes due to changes in mobile banking strategy. The adjusted $\mathrm{R}$ square indicates that mobile banking strategies adopted in this study explain $95.3 \%$ change in financial inclusion.

Table 5: Model Summary

\begin{tabular}{lcccc}
\hline Model & $\mathbf{R}$ & R Square & $\begin{array}{c}\text { Adjusted R } \\
\text { Square }\end{array}$ & $\begin{array}{c}\text { Std. Error of } \\
\text { the Estimate }\end{array}$ \\
\hline 1 & $.978^{\mathrm{a}}$ & .956 & .953 & .45941 \\
\hline
\end{tabular}

a. Predictors: (Constant), transfers, withdrawals, deposits

Analysis of variance was adopted to conduct the goodness of fit test where the significance of the overall model was assessed as shown in Table 6:

Table 6: ANOVA

\begin{tabular}{llccccc}
\hline Model & & $\begin{array}{c}\text { Sum of } \\
\text { Squares }\end{array}$ & df & $\begin{array}{c}\text { Mean } \\
\text { Square }\end{array}$ & F & Sig. \\
\hline 1 & Regression & 209.111 & 3 & 69.704 & 330.261 & $.000^{\mathrm{b}}$ \\
& Residual & 9.709 & 46 & .211 & & \\
& Total & 218.820 & 49 & & & \\
\hline
\end{tabular}

a. Dependent Variable: Financial inclusion

b. Predictors: (Constant), transfers, withdrawals, deposits 
F-Statistic value was 330.261 at $3 \mathrm{df}$. This implies that mobile banking strategy can prognosticate financial inclusion. Mobile banking strategy was operationalized using (transfers, withdrawals and deposits via a mobile platform. The unstandardized beta coefficient for mobile funds transfers was 1.697. This meant that when it changes by one unit, financial inclusion follows suit by 1.697. The unstandardized beta coefficient for cash withdrawals was 1.195, implying that a unit change in cash withdrawals via mobile platform influenced 1.195 changes in financial inclusion. Deposits via mobile platform had .354. When deposits via mobile platform change by a unit, financial inclusion follows suit by .354 .

Table 7: Regression coefficients

\begin{tabular}{llccccc}
\hline Model & & \multicolumn{2}{c}{$\begin{array}{c}\text { Unstandardized } \\
\text { Coefficients }\end{array}$} & $\begin{array}{c}\text { Standardized } \\
\text { Coefficients }\end{array}$ & t & Sig. \\
\hline \multirow{3}{*}{1} & & $\boldsymbol{\beta}$ & Std. Error & Beta & & \\
& (Constant) & 49.927 & 2.888 & & 17.285 & .000 \\
& Transfers & 1.697 & .149 & 1.490 & 11.391 & .000 \\
& Withdrawals & 1.195 & .121 & 1.136 & 9.846 & .000 \\
& Deposits & .354 & .043 & .419 & 8.211 & .000 \\
\hline
\end{tabular}

a. Dependent Variable: Financial inclusion

The study had proposed that mobile banking strategy has no significant effect on financial inclusion among Commercial Banks in Kenya $\left(\mathrm{H}_{0} 1\right)$. The effect was found to be significant $(\mathrm{p}<0.05)$, as espoused in Table 7 . Therefore, the null hypothesis was rejected, implying that mobile banking significantly affects financial inclusion among Commercial Banks in Kenya. The study results are in agreement with the findings of Ngugi (2015), Wakaba and Wepukhulu (2019), Musango (2018) that mobile banking has a significant effect on financial inclusion among Commercial Banks in Kenya.

\section{Conclusion and Recommendations}

The study concludes that mobile banking has a significant effect on financial inclusion among commercial banks in Kenya. The use of mobile funds transfers, cash withdrawals via mobile platform and deposits via mobile platform have a significant effect on financial inclusion. Mobile banking strategies lead to expanding financial services to non-financial sectors and expanding essential services to individuals. Mobile banking helps banks as suppliers or providers of financial services lower costs by reducing queuing lines in banking halls, reducing manual paperwork and documentation, and maintaining fewer bank branches. The study recommends that all financial institutions should adopt mobile banking as it helps to achieve financial inclusion. The banking sector should adopt the most appropriate mobile banking strategies to enhance financial inclusion. This is because the strategies help delineate all financial services to be delivered to a disadvantaged group of people at an affordable cost as per their needs and requirements. They also help bring the unbanked and under-banked people into the financial system to provide them with the opportunity to access the financial services to create economic growth and lead to empowerment opportunities. 


\section{References}

Akter, U., Anwar, S. R., Mustafa, R., \& Ali, Z. (2021). Revisiting the impact of mobile banking on financial inclusion among the developing countries. International Journal of Financial Research, 12(2), 62-74.

Bara, A., \& Mudzigiri, C. (2016). Financial innovation and economic growth: Evidence from Zimbabwe. Investment Management and Financial Innovations, 13(2), 111-118.

Boro, M. (2017). Effect of mobile banking on financial inclusion in Kenya. Unpublished masters' thesis, University of Nairobi.

Businge, J. (2018). Usage of mobile banking services and financial inclusion of rural populations in Rwanda. Unpublished master's thesis. University of Rwanda.

Blaise, N., \& Kosgei, F. (2021). Mobile banking and financial inclusion in Burundi. IOSR Journal of Economics and Finance (IOSR-JEF), 12(2), 60-68.

Ishengoma, R.P.B.A. (2011). Analysis of mobile banking for financial inclusion in Tanzania: case of Kibaha District Council. IOSR Journal of Economics and Finance (IOSR-JEF), $1(1), 15-21$.

Kabala, E., Mapoma, R., Nalutongwe, C., Muyani, D., \& Lungu, J. (2021). An ethnological analysis of the influence of mobile money on financial inclusion: The case of urban Zambia. Zambia Social Science Journal, 7(1), 53-76.

Keli, J. (2018). Effect of mobile technology on financial inclusion in Kitui County, Kenya. Unpublished master's thesis. Moi University.

Kigen, K. P. (2010). The impact of mobile banking on transaction costs of microfinance institutions. Unpublished master's thesis, University of Nairobi.

Kothari, C. R. (2004). Research methodology: methods and techniques (2 ${ }^{\text {nd }}$ ed.). New Delhi: New Age International.

Lenka, S. K., \& Barik, R. (2018). Has expansion of mobile phone and internet use spurred financial inclusion in the SAARC countries?. Financial Innovation, 4(1), 1-19.

Lind, A.D., Marchal, G.W., \&Wathen, A.S. (2012). Statistical techniques in business \& economics $\left(15^{\text {th }}\right.$ ed.). New York, USA: McGraw-Hill/Irwin.

Mago, S., \& Chitokwindo, S. (2014). The impact of mobile banking on financial inclusion in Zimbabwe: A case for Masvingo Province. Mediterranean Journal of Social Sciences, 5(9), 221-221.

Manyika, J., Lund, S., Singer, M., White, O., \& Berry, C. (2016). Digital finance for all: Powering inclusive growth in emerging economies. International Journal of Finance and Accounting, 1(1), 1-8. 
Musango, D.M. (2014). Mobile banking services and financial inclusion among commercial Banks in Nairobi city county, Kenya. Unpublished master's thesis, Kenyatta University.

Mutsune, T. (2014). No Kenyan left behind: The case of financial inclusion through mobile banking. In Global Conference on Business \& Finance Proceedings (Vol. 9, No. 1, p. 472). Institute for Business \& Finance Research.

Mtetwa, F. (2018). The impact of mobile banking on financial inclusion. Unpublished masters' thesis, University of Zimbabwe.

Ngugi, D. (2015). Relationship between mobile banking and financial inclusion in Kenya. Unpublished masters' thesis, University of Nairobi.

Olweny, T., \& Shipho, T.M. (2011).'Effects of banking sectoral factors on the financial performance of commercial banks in Kenya," Economic and Finance Review, 1(5), 130.

Saunders, M., Lewis, P., Thornhill, A., \& Wilson, J. (2009). Business research methods. London: Financial Times, Prentice-Hall.

Sharma, P. P., Khan, S. A., \& Thoudam, P. (2019). Role of attitude and entrepreneurship education towards entrepreneurial orientation among business students of Bhutan. International Journal of Recent Technology and Engineering, 8.

Usavi, V. (2014). An analysis of the impact of mobile banking on financial inclusion in Zimbabwe (A case study of Buhera District). Unpublished master's thesis. Bindura University of Science Education.

Wakaba, V., \& Wepukhulu, J. M. (2019). Effect of mobile money services on Kenya's financial inclusion. International Journal of Finance and Accounting, 4(2), 1-18.

Williams, R. (2015, August). Multicollinearity. Retrieved from https://www3.nd.Edur william/stats2/i11.pdf

World Bank (2004). Have a mobile phone - World Bank documents. Retrieved from https://documents.worldbank.org/curated/en/961621467994698644/pdf/102724-WDRWDR2016Overview-ENGLISH-WebResBox-394840B-OUO-9.pdf

Yawe, B., \& Prabhu, J. (2015). Innovation and financial inclusion. A review of literature. Journal of Payments, Strategy \& Systems, 9(3), 71-79.

\section{Copyrights}

Copyright for this article is retained by the author(s), with first publication rights granted to the journal.

This is an open-access article distributed under the terms and conditions of the Creative Commons Attribution license (http://creativecommons.org/licenses/by/4.0/) 